STUDIA SPORTIVA 2013 / č. 3, s. 137-145

\title{
Drums Alive® - bubnování na gymnastických míčích jako prostředek rozvoje koordinace
}

\section{Drums Alive ${ }^{\circledR}$ - drumming on exercise balls as the mean of development of coordination}

\author{
Věra Knappová, Gabriela Kavalířová \\ Pedagogická fakulta, Západočeská univerzita v Plzni, \\ Česká republika
}

\section{Abstrakt:}

Kvalita koordinace pohybu významně ovlivňuje každodenní život člověka a vytváři předpoklady pro efektivni osvojováni pohybových dovedností. Mezi základní radíme stabilitu, lokomočni pohyby a manipulaci s objekty (Doty, McEven, Parker \& Laskin, 1999). Mnohé z nich nejsou mnohdy jedinci s postižením schopni vykonávat na stejné úrovni jako jejich nepostižení vrstevnici. Nedostatky koordinace pohybu se mohou negativně promitat do kvality jejich života.

Na základě poznatkủ publikovaných o vhodných pohybových intervencich na rozvoj koordinace pohybu u jedinců bez postiženi můžeme aplikovat individuálně prizpưsobené specifické pohybové činnosti i na jedince s různým postižením. Náš př́spěvek je zaměren na využití nového směru hudebně-pohybové terapie Drums Alive ${ }^{\circledR}$ (bubnováni na gymnastických míčich). Drums Alive ${ }^{\circledR}$ je metoda spojujíci dynamické a taneční pohyby s pulsujicím rytmem bubnů. Jedná se o senzomotorický program, jež autorka Carrie Ekins koncipovala na základě spojení bubnování a cílené pohybové aktivity (Ekins, 2012). Prostřednictvím těchto aktivit lze cíleně ovlivňovat kvalitu a úroven̆ motorických dovedností a lepši koordinaci pohybu využitelného především v běžném životějedinců s postižením. 


\section{Abstract:}

Quality of coordination of movement significantly influences everyday life of a man and creates preconditions for effective acquiring motor skills. Stability, locomotor movement and manipulative movement belong among fundamental motor skills (Doty, McEven, Parker \& Laskin, 1999). People with disability are not often able to perform many of them on the same level as their same-age peers without disability. Imperfections in movement coordination can be negatively reflected in quality of their life.

On the basis of published knowledge about appropriate movement interventions on development of movement coordination by people without disability we can apply individually adjusted specific movement programs for people with various disabilities. Our paper is focused on use of new specialization of music-movement therapy Drums Alive ${ }^{\circledR}$ (drumming on exercise balls in holders). Drums Alive ${ }^{\circledR}$ joins the dynamic and dance movements with the pulsating rhythms of the drums. It is sensorimotor program, which the author Carrie Ekins designed as combination of drumming activities and targeted movement activity (Ekins, 2012). By means of these activities it is possible to influence the quality and level of motor skills and better movement coordination used primarily in common life of disabled people.

Klíčová slova: bubnování na gymnastických míčich, koordinace, pohybové dovednosti.

Key words: drumming on exercise balls, coordination, motor skills.

\section{ÚVOD}

\section{Formulace problému}

Kvalita koordinace pohybu významně ovlivňuje každodenní život člověka a vytváří předpoklady pro efektivní osvojování pohybových dovedností. Mezi základní pohybové dovednosti řadíme stabilitu, lokomoční pohyby (chůze, běh, poskoky, skoky, cval) a manipulaci 
s objekty (házení, chytání a kopání) (Doty, McEven, Parker a Laskin, 1999; Gallahue, 1996). Mnohé z těchto pohybových dovedností nejsou často jedinci s postižením schopni vykonávat na stejné úrovni jako jejich nepostižení vrstevníci. Poruchy v oblasti koordinace pohybu se projevují v běžných denních aktivitách např. zhoršeným načasováním pohybu, nepřesným zacílením provedeného pohybu, zhoršenou plynulostí pohybu, nerovnováhou, mírným třesem apod. Nedostatky v koordinaci pohybu se promítají do kvality života těchto jedinců a negativně ovlivňují mimo jiné i jejich psychickou stránku a postavení ve skupině.

\section{HLAVNÍ ČÁST}

\section{Možnosti řešení problému}

V praxi se momentálně věnujeme testování a rozvoji motoriky u dětí s mentálním a smyslovým postižením. Spolupracujeme se ZŠ speciální v Plzni a občanským sdružením ProCit v Plzni.

Naší náplní je stanovení a realizace vhodné pohybové intervence zaměřené na ty oblasti, ve kterých testováním zjistíme nižší úroveň pohybových dovedností. Ke zjišsění úrovně koordinace pohybu použiváme testovou baterii pro hrubou i jemnou motoriku MABC2 (Movement Assessment Batery for Children 2) (Henderson, Sugden \& Bernett, 2007). Testování je zaměřeno na tři základní oblasti koordinace - manuální zručnost, dovednosti s míčem a statickou a dynamickou rovnováhu.

Na základě poznatků o vhodných pohybových intervencích cílených na rozvoj koordinace pohybu u intaktních dětí aplikujeme individuálně přizpůsobené specifické pohybové činnosti $\mathrm{i}$ na děti $\mathrm{s}$ mentálním postižením. Jako vhodné se jeví napřr. využití prostředků rytmické gymnastiky (hudebně pohybová výchova, lokomoční pohyby, manipulace s náčiním, rovnováhová průprava), prvků psychomotoriky, některých fyzioterapeutických postupů a pomůcek apod. Prostřednictvím těchto aktivit lze cíleně ovlivňovat kvalitu a úroveň pohybových dovedností a zlepšovat koordinaci pohybu využitelného především v běžném životě jedinců s postižením. 


\section{Drums Alive ${ }^{\circledR}$}

$\mathrm{V}$ našem prŕspěvku jsme se zaměřili na využití nového směru hudebně-pohybové terapie Drums Alive ${ }^{\circledR}$ (bubnování na gymnastických míčích). Drums Alive ${ }^{\circledR}$ je metoda spojující jednoduché dynamické a taneční pohyby s pulsujícím rytmem bubnů (Ekins, 2012). Jedná se o senzomotorický program, jejž autorka Carrie Ekins v roce 2001 koncipovala na základě spojení bubnování a cílené pohybové aktivity. Impulsem k vytvoření tohoto programu bylo její zranění, které ji na čas výrazně omezilo v pohybu. První workshopy byly prezentovány v USA, následně v Německu a rozšírilily se i do dalších zemí světa.

Cílem programu Drums Alive ${ }^{\circledR}$ je optimalizace kvality života zúčastněných osob.

Využívány jsou poznatky a prostředky $\mathrm{z}$ taneční terapie, muzikoterapie, psychomotoriky, rytmické gymnastiky, moderních pohybových forem a fitness. Rytmické pohyby jsou pro bubnující estetickým zážitkem a potěšením, vybrané prvky bubnování iniciují sociální kontakty. Pohyb založený na vnímání a vytváření rytmu, a ne na soutěživosti a snaze o dokonalost, zesiluje emoční a tělesné procesy, komunikaci a kreativní složky motorického učení.

Jedná se o hromadnéčiindividuální cvičenípřizpůsobené specifickým potřebám jedinců. Bubnování je vhodné pro širokou různorodou veřejnost. Můžeme zde terapeuticky pracovat s dětmi, dospělými i seniory, s jedinci na jedné straně mentálně a tělesně nadanými, ale i osobami se specifickými potřebami či neurologickými onemocněními (např. osoby se sklony k agresi, pacienti s Parkinsonovou nemocí, Alzheimerem, mozkovou mrtvicí a další). Bubnovat může každý, i ten, který by se k této činnosti vzhledem ke své jinakosti běžně nedostal. Rytmická schopnost je totiž podle Válkové (2012) v určité míře dána každému jedinci, i tomu znevýhodněnému. Je nutné pouze přizpůsobit podmínky a pomůcky a zvolit stupeň obtížnosti.

Jedná se o činnost finančně a prostorově nenáročnou. Potřebujeme k ní paličky na bubnování, gymball umístěný v plastovém koši, který slouží k fixaci míče, a vhodný hudební doprovod. Hudební doprovod 
vybíráme citlivě s ohledem na jedince, pro něž je terapie určena. Hudba stimuluje rytmus, vyvolává prožitky a pocit uspokojení, motivuje k pohybu, což je u práce s jedinci s postižením primární snahou terapeuta.

Drums Alive ${ }^{\circledR}$ je nejen zábavným cvičením, ale zároveň se jedná i o cílenou stimulaci celého organismu v oblasti fyzické, psychické a sociální. Podle Ekins (2012):

- Bubnování vylad’uje autonomní nervový systém ve smyslu převahy parasympatiku, tím výrazně redukuje stres a posiluje imunitní systém.

- Bubnování zlepšuje synchronizaci obou mozkových hemisfér. Synchronizace pravé a levé hemisféry vykazuje stimulaci aktivity mozkových alfa vln, což může vést k vyšší úrovni koncentrace, senzorickému a motorickému zdokonalení a celkové duševní pohodě.

- Bubnování, podobně jako jiné aerobní pohybové aktivity, lze využít jako prostředek zvyšování fyzické zdatnosti (zvyšování srdeční a dechové frekvence, vyplavování endorfinů, cílené posilování svalových skupin aj.).

Ekins (2012) uvádí pozitivní prrínos Drums Alive ${ }^{\circledR}$ při rehabilitaci u pacientů s neurologickými patologiemi, jako je např. Alzheimerova choroba, mozková mrtvice aj. V rámci rehabilitace může tato terapie také pomoci při synchronizaci pohybů a zlepšení rychlosti a symetrie pacientovy chůze.

Pro názornost uvádíme vybrané základní pozice a údery užívané při bubnování, viz tab. 1 a 2.

Tab. 1: Základní bubnování - pozice

\begin{tabular}{|l|l|}
\hline Base position 1 - Základní pozice 1 & \\
\hline $\begin{array}{l}\text { Šroký podřep rozkročný - mírně pokrčené paže, } \\
\text { paličky na míči. Rovná záda, hlava v prodloužení } \\
\text { páteře. }\end{array}$
\end{tabular}




\begin{tabular}{|l|l|}
\hline Base position 2 -Základní pozice 2 \\
\hline $\begin{array}{l}\text { Podřep zánožný - koleno nad špičkou chodidla, } \\
\text { chodidlo zadní nohy celou plochou na zemi, boky } \\
\text { směřují vpřed. }\end{array}$ \\
\hline Split ball - Rozdělený míč \\
\hline $\begin{array}{l}\text { Stoj mezi dvěma míči, každá palička na jednom } \\
\text { míči. }\end{array}$
\end{tabular}

Tab. 2: Základní bubnování-údery

\begin{tabular}{|l|}
\hline Singles - Jednoduché údery \\
\hline $\begin{array}{l}\text { Základní pozice 1, úder jednou paží (paličkou), } \\
\text { druhá paže je lehce zvednutá. Umístění paličky } \\
\text { může být na vrchní, levou/pravou, přední či zadní } \\
\text { stranu míce. }\end{array}$ \\
\hline Doubles - Dvojité údery \\
\hline $\begin{array}{l}\text { Základní pozice 1, úder na míč oběma pažemi } \\
\text { (paličkami). }\end{array}$ \\
\hline Side Ball - Levá/pravá strana míče \\
\hline $\begin{array}{l}\text { Základní pozice 1, doubles na levou/pravou stranu } \\
\text { míče. }\end{array}$
\end{tabular}




\begin{tabular}{l}
\hline Front Ball - Přední strana míče \\
Základní pozice 1, doubles na přední stranu míče. \\
\hline Back Ball - Zadní strana míče \\
Základní pozice 1, úkrok vzad od míče a doubles na \\
zadní stranu míče. \\
\hline Overhead Clicks - Klepnutí nad hlavou \\
Základní pozice 1, klepnout paličkami o sebe nad \\
hlavou. \\
\hline Side Beats - Po stranách míče \\
Základní pozice 1, současný úder pravou paličkou \\
na pravé straně míče a levou paličkou na levé straně \\
míce.
\end{tabular}




\begin{tabular}{|l|}
\hline $\begin{array}{l}\text { Extended Singles - Prodloužené jednoduché } \\
\text { údery }\end{array}$ \\
\hline $\begin{array}{l}\text { Základní pozice 1, střídavě provést prodloužený } \\
\text { single úder na míč - paže (palička) předpažením } \\
\text { vzpažit. }\end{array}$ \\
\hline $\begin{array}{l}\text { Extended Doubles (,Reach”) - Prodloužené } \\
\text { dvojité údery (,Dosáhnout vysoko“) }\end{array}$ \\
$\begin{array}{l}\text { Základní pozice 1, provést prodloužený double úder } \\
\text { na míč - paže (paličky) předpažením vzpažit. }\end{array}$ \\
\hline Brush or Sway - „Zametání nebo Zhoupnutí‘ \\
Základní pozice 1, paže (paličky) opisují dolní \\
oblouk jemně přes vrchní část míče zprava doleva - \\
„zametají / houpají se“.
\end{tabular}

Možným metodickým pokračování uvedených základních prvků je přidání lokomočních pohybů, využívaných napřr. v moderních pohybových formách (step touch, V-step, chůze okolo míče, grapevine, chasse apod.).

Klademe-li důraz více na sociální funkci bubnování, sdružujeme skupinu cvičenců do různých útvarů - jedna a více řad, malý či velký kruh, čtverec a další.

Spojováním různých prvků bubnování a lokomoce vznikají zajímavé choreografie.

\section{ZÁV̌̌R}

$\mathrm{V}$ předkládaném př́spěvku jsme se zaměřili na novou možnost vhodné terapie u jedinců s mentálním postižením, Drums Alive ${ }^{\circledR}$ (bub- 
nování na gymnastických míčích), která v sobě spojuje pohybovou intervenci s výraznou rytmickou složkou při hudebním doprovodu. Spojením pohybu pravé a levé ruky s vnímáním a vyjadřováním různých rytmů, popř. s lokomočními pohyby, dochází ke zlepšení koordinace pohybu. Při bubnování se synchronizují obě mozkové hemisféry, přičemž se stimuluje aktivita mozkových alfa vln. To může vést $\mathrm{k}$ senzorickému a motorickému zdokonalení, duševní pohodě, a tím k zlepšení celkové kvality života zúčastněných. $\mathrm{V}$ tom vidíme velký přínos této pohybové aktivity právě pro jedince s mentálním postižením.

\section{LITERATURA}

Doty, A., McEven, I., Parker, D., \& Laskin, J. (1999). Effects of testing context on ball skill performance in 5-year-old children with and without developmental delay. Physical Therapy, 79, 818-826.

Ekins, C. (2012). Drums Alive ${ }^{\circledR}$ - Instructor Manual.

Gallahue, D., L. (1996). Development physical education for today's children. Dubugue, IA: Brown \& Benchmark.

Henderson, S. E., Sugden, D. A., \& Bernett, A. L. (2007). Movement Assessment Battery for Children - 2. London: Copyright.

Válková, H. (2012). Teorie aplikovaných pohybových aktivit pro užití v praxi 1. Olomouc: UP v Olomouci.

\section{KONTAKT:}

Mgr. Věra Knappová, Ph.D., knappova@ktv.zcu.cz 